\title{
TRANSPARENCY MECHANISMS AND MANAGEMENT OF PUBLIC CONTRACTS IN BRAZIL: THREE CASE STUDIES ON THE FEDERAL PUBLIC ADMINISTRATION
}

\author{
Têmis Limberger ${ }^{1}$ \\ Anderson Vichinkeski Teixeira ${ }^{2}$
}

\begin{abstract}
The overall objective of this study is to analyze mechanisms for managing the execution of public contracts by the Federal Public Administration, such as inspection, quality control and deadlines, application of legal and administrative sanctions and promoting transparency in order to protect the public interest involved as well as to produce diagnoses that generate alternatives to overcome the main problems such as gifts in the management process, given the interdisciplinary nature of the research based on the contribution of different regions of Brazil. The methodology of empirical research was based on the quantitative aspect, from varying tables, and the qualitative aspect, from the wealth of information collected. The results presented demonstrated that electronic trading prevailed as the bidding modality of contracts surveyed. This helped to establish conclusions about the proposals for legislative improvement suggested, including the possibility of implementing control of the execution of public contracts for results.
\end{abstract}

Keywords: Federal Public Procurement Administrative Management; Efficientism; Models of Private Management.

\section{INTRODUCTION}

The various globalization processes have increased competitiveness in almost all sectors of the economy and business, making performativity the main characteristic of business management in a post-modern society, i.e., as Lyotard (1979) put it, the maximum output for the least inputpossible.

The growing pressure to promote accountability and improvement of public sector performance is a process of international dimensions which has also become increasingly important in Brazil. Therefore, the

\footnotetext{
${ }^{1}$ Professor of Administrative Law at the University of the Rio dos Sinos Valley (UNISINOS/Brazil). Ph.D in Public Law at the University Pompeu Fabra, Barcelona (Spain). Visiting Professor at the University of Sevilla (Spain). LL.M. in Public Law at the Federal University of Rio Grande do Sul (UFRGS/Brazil). Prosecutor at the Tribunal of Justice of the State of Rio Grande do Sul. . ${ }^{2}$ Professor of Constitutional Law at the University of the Rio dos Sinos Valley (UNISINOS/Brazil). Ph.D in Theory and History of Law at the University of Florence (Italy). Visiting Scholar at the University of Paris, Sorbonne (France). Visiting Professor at the University of the Republic of Uruguay. He also serves as Editor of RECHTD - Revista de Estudos Constitucionais, Hermenêutica e Teoria do Direito. Lawyer and legal consultant.
} 
demands for improvement in the management of public organizations create a focus on the need for greater attention to performance than to formal aspects of regulation, especially in managing the execution of public contracts, in which the normative framework calls for restrictions that affect the mechanisms of choice of the best proposal to be given a contract by PublicAdministration.

Since Public Administration carries out multifarious and complex activities, always in the public interest (Carvalho Filho, 2008), Law no 8,666, of June 21, 1993, which deals with tenders, was a legislative evolution which, besides innovations on the topic, provided an alternative for rendering the rules for contracts made by Public Administration compatible with the system established by the Federal Constitution of 1988. Thus, one can claim that tendering "is a procedure by which Public Administration and its controlled entities arrive at the selection of the best proposal catering to the public interest for the signing of an administrative contract. It is a procedure that has control rules and is imbued with constitutional principles related to Administration such as legality, morality and publicity, among others" (Torres, 2008). It must not be forgotten that the principle of the requirement of a tender for the provision of services and execution of works stems from article 37, subsection XXI of the Federal Constitution and that this is the fundamental basis for understanding legislation on tenders.

The types of tender in Brazil are listed in article 22 of Law no 8,666/93 (public bidding, price quotation, invitation, competition and auction). The legislator did not include the type of tender consisting of bidding, which is contained in Law no 10,520/2002. Bidding is used for the acquisition of goods and for contracting ordinary services no matter what the value of the contract is. The selection procedure is characterized by open sessions in which the bids are presented and by a later examination of the bidder's qualifications. Bids can be made by the bidder at the session or electronically. The procedure has proven to be a faster and more transparent form of public contract management.

In the case of Brazilian, according to Fiuza (2012, p. 7), the restrictions imposed by the regulatory structure are a limiting factor for public investment. Unlike private corporations, which are relatively free to choose their suppliers, public managers must normally comply with much more rigid criteria in selecting their suppliers and pricing their purchases, as they must adhere to the principles of impersonality, equality, legality and publicity, amongst others, thereby leaving very little freedom for the action of public managers.

Since the private sector usually does not have to act under such restraints (Tadelis, 2012), recent research in the field of Economic Analysis of Law suggests that the greater flexibility of the private sector contracts offers advantages in terms of efficiency and therefore claims that there is a need to reinforce the tools that are available to public administrators charged with the management of publiccontracts. 
Analyzing the subject of tenders within Comparative Law, particularly in the Common Law countries, such as the United States and the U.K., one finds that there is a similarity between Brazilian and international law with respect to the format for making contracts within the sphere of Public Administration.

In the United States, at federal level the regulation of the format of Public Administration contracts is contained in the Federal Acquisition Regulation (FAR) ${ }^{3}$, as established in Title 48, Chapter 1 of the United States Federal Rules Code. It should be stressed that the FAR rules are general and each regulating agency has the competence to create special standards, which complement the rules set out in FAR.

The purchasing process instituted by FAR, just as the Brazilian Tendering Law, establishes general principles which must be observed when contracts are made, covering procedure uniformization, low cost, quality and punctuality, administrative operational cost minimization, carrying out business with integrity, fairness and openness and compliance with other public policyobjectives. ${ }^{4}$

The European Union establishes general rules on Government Procurement. There are essentially four methods to be followed by governments: (1) lowest price, (2) the economically most advantageous deal, (3) average amount and (4) the exclusion of extremes. ${ }^{5}$

One pertinent similarity that must be highlighted is that the European Union has the Public Tendering system $^{6}$, which is similar to the Brazilian Electronic Bidding System. According to Bandeira (2005), the European system:

created the Common Procurement Vocabulary - CPV, which consists of standardized descriptions of products and services referring to more than 8,300 nine-digit codes, the use of which is strongly encouraged in disseminating requests for tenders. This is an essential step towards enabling the exchange of information in an area with so many official languages such as the European Community.

In practice the $\mathrm{CPV}$ is linked to the objective of the official tender notice, associating it to a standardized list of goods and services. If, for instance, a Danish company that produces films for educational purposes or for training wanted to obtain contracts within the European Union, it would not have to know all possible linguistic variations of its product for the purpose of looking for official notices of tenders. It would only have to look up the code in the CPV and would have all the offers published at its disposal.

It is estimated that in Brazil public purchases by the Union, States and Municipalities represented approximately 6.7\% of the GDP in 2005 (Fernandes Jr. and Furtado, 2005). According to data supplied by the Ministry for Planning (2012) in 2012 purchases by Public Administration represented 10\% of the Brazilian GDP.

\footnotetext{
${ }^{3}$ See [48 FR 42103, Sept. 19, 1983, as amended at 51 FR 27116, July 29, 1986] 48 C.F.R. 1.101 (2012). Retrieved from http://www.ecfr.gov/cgi-bin/text-idx?SID=25f471a7a6512b124af4e03f8f12ec6e\&node=48:1.0.1.1.1.1.1.1 \&rgn=div8 ${ }^{4}$ See [60 FR 34733, July 3, 1995] 48 C.F.R. 1.102 (2012). Retrieved from http://www.ecfr.gov/cgi-bin/textidx?SID=25f471a7a6512b124af4e03f8f12ec6e $\&$ node=48:1.0.1.1.1.1.1.2\&rgn=div8

${ }^{5}$ See Article 53, of 2004/18/EC Directive coordinating the procurement procedures. Retrieved from http:// eurlex.europa.eu/LexUriServ/LexUriServ.do?uri=OJ:L:2004:134:0114:0240:en:PDF

${ }^{6}$ See http://www.publictendering.com
} 
Given this context, our research project was aimed at checking the procedures of management in the execution of administrative contracts by state agencies and how mechanisms for inspection, transparency, control of quality and compliance with deadlines and the application of legal-administrative sanctions have been implemented in the pursuit of the public interest.

Besides this the research project sought to point out the problems and lack of definitions present in the process of execution of the administrative contracts. At the end it brings up proposals for improving the system of public contracting and public management of contracts, mainly concerning indirect Public Administration.

\section{OBJECT AND OBJECTIVES OF THE RESEARCH PROJECT}

The object of investigation consists of the mechanisms of management of the execution of administrative contracts by the following agencies/organizations of the Brazilian Federal Public Administration (FPA), which are respectively a public corporation, an autarchy and a public corporation:

1. Caixa Econômica Federal (CAIXA/RS): one of the most important public banks in Brazil.

2. Fundação Oswaldo Cruz - Centro de Pesquisas Gonçalo Moniz (FIOCRUZ/BA): a scientific institution for research and development in biomedical sciences; the Unit of FIOCRUZ based in the State of Bahia was the one surveyed in thisresearch.

3. Empresa Brasileira de Infraestrutura Aeroportuária (INFRAERO/RS): the Brazilian public corporation responsible for operating the main Brazilian airports; the Unit of INFRAERO based in the State of Rio Grande do Sul was the one surveyed in this research.

It should be mentioned that each one of the organizations surveyed uses a specific platform for contracting: whereas INFRAERO and CAIXA use their own data processing systems, FIOCRUZ uses the Brazilian government's Comprasnet ${ }^{7}$ (the official portal of the Federal Government forpurchasing).

On the other hand, the general objective of the research project was to perform a diagnosis on the management of the execution of administrative contracts by state agencies within the scope of the Federal Government. It analyzes: (1) how the inspection, control of quality and deadlines, application of legaladministrative sanctions and promotion of transparency are implemented, in such a way as to protect the public interest involved; and (2) the problems and lack of definitions present in the process of managing the execution of these administrative contracts, raising a few issues that remain open in the discussion of this topic.

In this sense the specific objectives are: (a) To perform a comparative analysis of the factors determining performance in terms of price and deadlines in the ex-ante phase, and also the factors that explain the concession of amendments (internal phase) in the administrative contracts whose objects have been contracted by means of 
electronic bidding, tenders and competition in the three public organizations researched; (b) To describe and analyze the operation and effectiveness of the management mechanisms adopted in the contract execution phase (internal phase) based on in-depth interviews performed with key players in the contracting process, and (c) To present and discuss legislative suggestions to improve the management systems of the administrative contracts by the public sector in terms of managerial practices and legal processes.

As to the typology of the time period covered by the research project, the horizon used varied according to the company researched. The peculiarities and idiosyncrasies of each organization were evaluated at the time of collection. In this sense, at FIOCRUZ, the period between 2005 and 2012 was considered, at INFRAERO, 2005 to 2011, and, finally, at the CAIXA the criterion observed was the contracts that ended in 2011.

After the consolidation of the quantitative data bases and the study of heterogeneity of information by means of an exploratory analysis of the data, it was possible to identify the determining factors of performance in the different types of tender during the contracting process (ex-ante phase) and during the execution of the contract (internal phase). These factors were evaluated using the multiple regression analysis technique with Stata 11 software.

Once these premises have been established, the main aspects found in the scientific investigation are presented below.

\section{OPERATIONAL CHECK OF ADMINISTRATIVE CONTROLS OF THE PROCUREMENT CONTRACT EXECUTION}

Among the main issues found, one of the most relevant was the monitoring and control of administrative contract execution, ascertained mainly based on the perception of the public agents involved in the process, who were heard in semi-structured interviews.

Summary Table I below shows the category execution, its subcategories (internal control; adaptation; deviations and penalties; and quality of the contracting) and topics for analysis. The topics for analysis were marked in the columns according to the number of citations of players interviewed in the research project (Summary Table II), taking into account the occurrence of citations on a given topic for analysis, the total number of citations and the frequency of occurrence and citations.

\footnotetext{
${ }^{8}$ The collection of information in qualitative research was performed by means of in-depth semi-structured interviews. The use of this technique helps understand the potentials and limits of the current models of the management of the execution of administrative contracts by the public sector. In the semi-structured interview technique, some questions are previously standardized to make answers compatible among the subjects, but other questions can be asked in greater depth or inserted during the interviews (Creswell, 1998).
} 
Summary Table I - Analysis of the content of the category "monitoring and control" according to the number of

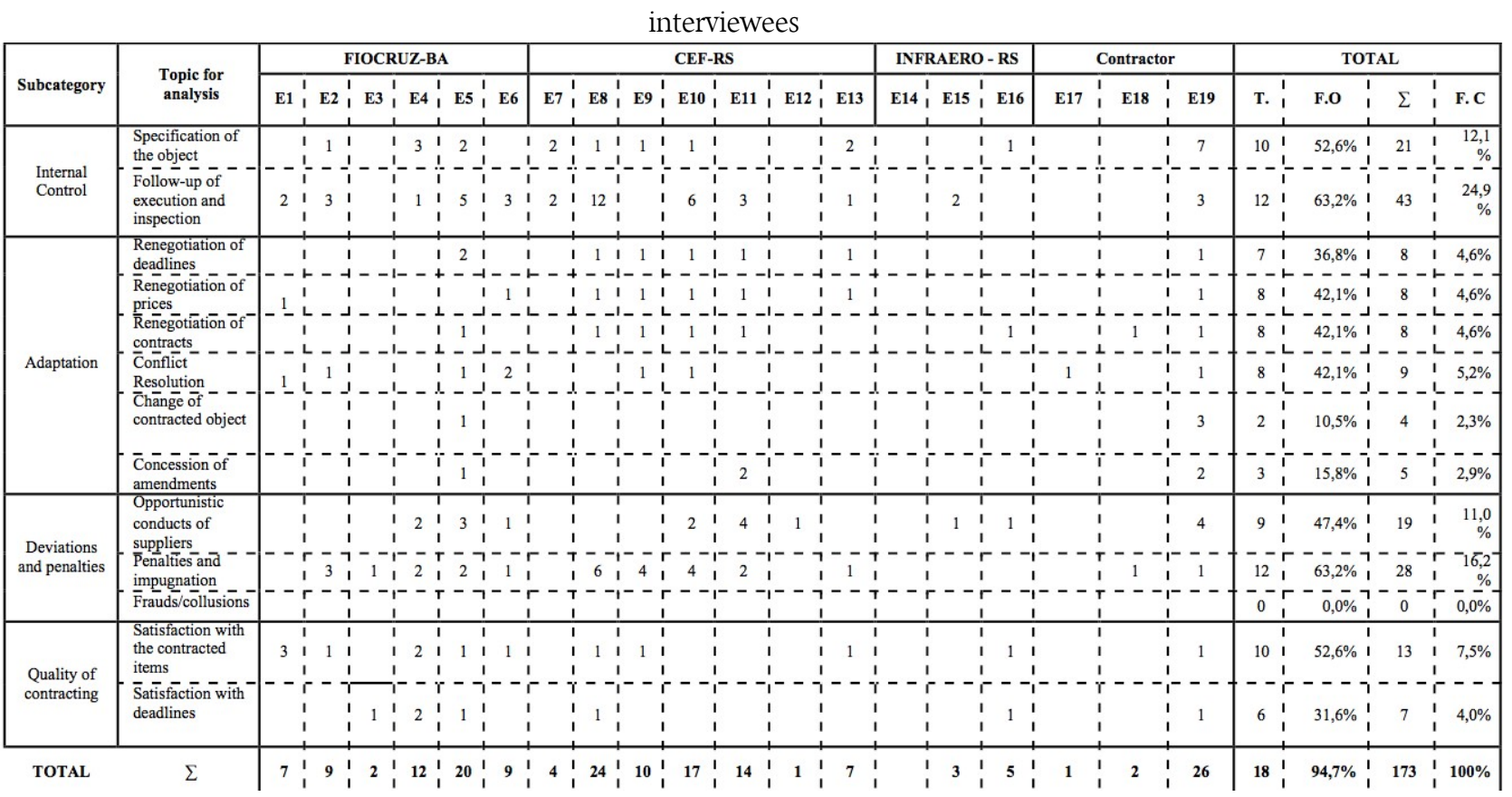

Note: $\mathrm{T}=$ total number of observations $/$ F.O.= Frequency of observation among all $/ \Sigma=$ Sum total of observation about the topic analyzed / F.C.= Frequency of citations in the category.

Source: Author et. al. (2013, p.52).

Summary Table II - Profile of theinterviewees

\begin{tabular}{|c|c|c|c|}
\hline \multicolumn{2}{|c|}{ FIOCRUZ-BA } & \multicolumn{2}{c|}{ CAIXA-RS } \\
\hline Interviewee & Code & Interviewee & Code \\
\hline Auctioneer & E1 & Coordinator oftenders & E7 \\
\hline Auctioneer & E1 & Maintenance coordinator & E8 \\
\hline Responsible for the stores & E3 & Services coordinator & E9 \\
\hline Engineer - inspector of works and services & E4 & Management assistant & E10 \\
\hline Manager and coordinator of contracts & E5 & Coordinator of formal management & E11 \\
\hline Representative of internal control & E6 & Senior assistant & E12 \\
\hline- & - & Representative of the LegalDepartment & E13 \\
\hline INFRAERO-RS & & PRIVATE MANAGERS & \\
\hline Interviewee & Code & Interviewee & Code \\
\hline Coordinator of tenders and contracts andauctioneer & E14 & Graphic services & E17 \\
\hline Commercial inspection & E15 & Logistic services & E18 \\
\hline Management and attorney & E16 & External contractor & E19 \\
\hline
\end{tabular}

Source: Author et. al. (2013, p. 51)

As an example of interpretation, one can see that the topic Specification of the contracted object, of the subcategory Internal control, occurred in the utterances of interviewees I2, I4, I5, I7 to I9, I13, I16 and I19, with a total of 10 remarks and frequency of $52.6 \%$ in the group of players researched (Summary Table I). Furthermore, 
one can notice that the topic was cited 21 times during the interviews, and interviewee I19 mentioned the topic 7 times during their utterance. As to the importance of the topic in the category, one can see that the number of citations of the topic is $12.0 \%$ of all citations that occurred in this category. In this sense, the tables referring to the other categories were analyzed in the same way. Also in this topic, it can be noted that in all organizations surveyed as well as in the interviews with the private managers the interviewees highlighted the importance of the process of specifying the item contracted to improve the management of the contract execution and for its satisfactory final performance.

According to the taxonomy proposed by Williamson (1985), the phase for the definition of the official notice and specification of the contracted object corresponds to the category of ex-ante transactional costs, involving the costs of gathering the information needed to: (i) construct the official announcement for selection; (ii) the specification of the characteristics of the item to be contracted for; (iii) definition of its indicators (measuring unit, quantity/volume needed, number of lots for delivery, and others); (iv) characterization of its forms of operation - in the case of services and works - or delivery - in the case of consumer goods - machinery and equipment, definition of funds and the flow of funds involved for the full performance of the functions contained in the official notice.

However, as can be concluded from the interview performed with the contracts coordinator of FIOCRUZ/BA (I5), "often the definition of the object of the contract is faulty, because of the lack of understanding of the procedures and of a more precise specification" (Author et al., 2013, p. 53). The lack of understanding of the modus operandi of the precise definition of the object, according to Tadelis (2012), may result in increased adaptation costs. In accordance with this concern, the coordinator for FIOCRUZ contracts states that "Incomplete contracts are always a problem and generate uncertainties and high costs to render them adequate" (Author et al., 2013, p.53).

Moreover, because of the characteristics of the contracting process in the public sector, there are situations in which the degree of contract specification is limited by restrictive legal issues. Another limitation of the process of detailing the specifications of the object contracted are the failures in planning, as told by a representative of the coordination of tenders at CAIXA/RS, who has over 30 years of experience (I7):

Thus, what I see in public administration in Brazil today is a great lack of planning. I hear lots of people say "Oh, tenders are an obstacle; because tenders have to contract the lowest price; because we make bad contracts" I don't think so... I think that the problem of bad contracts is because there is no planning whatsoever. The official announcements arrive and then it is all hurry, hurry, without time to think. So you have to do the public notice in 3, 4 days. Clearly in this situation your quality is going to be extremely flawed ... Because, for you to work well on an official notice, you must have time, you must have knowledge, and you have to have time. (Author et al., 2013, p.53).

Although there are legal restrictions and lack of planning that limit the object specification process, it is possible to circumvent them, as emphasized by a representative of the coordination of services at CAIXA/RS (I9). 
The interviewee reports a strategy to improve the level of detail and the quality of specifications of the contracted items "Normally takes place through working groups, one writes a standard official notice in which one defines the object, the responsibilities of the company contracted, the responsibilities of the job specifically, and this remains in a kind of library that we have of these terms of reference, as we call them" (Author et al., 2013, p. 54)

Another major way to improve the process of specifying the contracted object is to use the Information and Communication Technologies (ICTs). The relevance of using these mechanisms, especially the use of exante problem solving groups, also appears to be perceived by the contractors, as can be observed in this utterance by the contractor interviewed in the Northeast region(I19):

A few companies already have what we could call a more structured planning department, a budget department, and they detect these flaws. In fact, in many agencies these discussion groups already exist, before the tender, where you can send all your doubts and they are obliged to answer within up to seventy-two hours before the tender. So possible points of doubt and so on are solved in advance. (Author et al., 2013, p.54).

As regards the consonance of the points made by the interviewees above with the literature on the subject, it should be emphasized that several surveys have been performed in private organizations using the theoretical lens of the Theory of Incomplete Contracts (Simon, 1951) to explain what are the consequences of the failures of specification for contract performance. According to Dalen, Moen and Riis (2005) and Tadelis (2012), public agents, because of their limited rationality, are not able to anticipate all possible contingencies in the phase of procurement and of drafting the contract. Thus the suppliers can explore incomplete points in the contracts (flaws in the specification of the contracted item) to renege the quality of the service in order to reduce their costs (Hart, Shleifer and Vishny, 1997).

Besides the process of specifying the object contracted, another topic of analysis in the Internal control subcategory which was highlighted in the utterances of the interviewees was following up the execution and inspection, with $63.2 \%$ frequency in the references and 24.6\% frequencies in the citations of the Monitoring and Control category. Notably, the mechanisms to follow up and inspect the execution of administrative contracts are determining factors of the performance of both public and private sector contracts. In the public sector, the effective monitoring of contracts enables governments to perform corrective actions when they are not satisfactorily executed. However, the follow-up of execution often runs into limiting factors such as the physical impossibility of following up closely the actions of the various contracts, because of the large number of contracts. As found during the interviews, although every contract has a person responsible for its follow-up and inspection, the reality of the public organizations surveyed shows that this follow-up has been very limited because of the lack of personnel (I10, I13 and IE15), low capacity, lack of internal infrastructure and resources, such as computerized systems (I5, I6, I10 and I11). 
Due to the lack of staff to perform this activity, a common practice in the Brazilian public sector, especially for service contracts and engineering works, is to employ an outsourced company to perform the monitoring and inspection work. However, this process may present problems due to the complexity in the process of specifying this second contract. The point of reflection now becomes who guards the guard? See below excerpt from the interview held:

We have no way, nor the installed capacity to manage to evaluate whether that contract was adequately inspected or not. We are in the hands of an outsourced service, because we do not have the installed capacity or human resources to be able to evaluate this too (\#115) (Author et al.,2013:55).

As to the lack of computerization in the follow-up process, as mentioned by the interviewees both from FIOCRUZ/BA and from CAIXA/RS (I5, I6, I10 and I1 1), this is an acknowledged problem which has already been discussed within the organizations, especially in the field of services and continuous contracts. ${ }^{9}$ The following passages taken from the interviews explain a lot about the acknowledgement of the need to improve the follow-up mechanisms in the companies surveyed:

As to the management of contracts, unfortunately so far there is not yet a computerized process for this.... (\#I5) (Author et al., 2013, p.55).

It would be useful to have systems to control, to quantify this amount of complaints. Good management of information to be able to identify really whether they are or not fulfilling a contract. Because if this does not exist, things become difficult, this is really an important fact, there must be control and then data must be created, to know whether there must be a penalty, whether one must rescind the contract ... If one manages to reach a level in which everything is digitized... (\#I11) (Author et al., 2013, pp.55-56).

We could have better controls. More effective controls to avoid such an onerous management. Some facilitators. Even in the company's IT department they could develop more tools to control the execution of services, which should be something with a national coverage of the company, corporate systems that would provide us with more support. Even in the matter of control of the formal management of contracts, corporate systems that would help calculate contract variations. One feels that there is very great lack in this field of dedicated technology, all this field of logistics. (\#110). (Author et al,, 2013, p. 56).

As a consequence of this limitation of staff and lack of computerized systems to follow up the execution of the contracts, control mechanisms in general are evoked only when failures and problems are identified and the managers responsible for inspection are told about them (I10). Thus, what has happened are only administrative inspections, mainly for sanctions, to the detriment of the operational inspection and constant monitoring of the contract, as reported by the representative of the internal control of FIOCRUZ/BA (I6): "Inspection occurs in the administrative, not in the operational sphere" (Author et al., 2013, p. 56).

\footnotetext{
${ }^{9}$ Regarding the contracts for goods, to acquire consumer goods and equipment, the follow-up process is less complex and is performed during the phase in which the material is received in the stores. Generally the control mechanisms are visual analysis of the product and comparing the specifications contained in the official notice to those presented in the invoice.
} 
The implications resulting from loss of control by the public manager regarding the actions, resolutions and decisions undertaken by the contractor during the execution of the contract and regarding the final performance of the contract generate a favorable environment to create a negative perception of the contractors as to the capacity and quality of the follow-up performed by the government. Thus, some suppliers may be skeptical about the government' capacity to monitor the performance and therefore feel motivated to develop activities that will reduce their costs and directly affect the quality of the contract execution. Furthermore, this absence of followup reflects directly on the managers' capacity to promote the necessary adjustments during the implementation of contracts.

In this same direction, in the subcategory Adaptation, the topics related to the costs of contract adjustment emerge, i.e. to the processes of making a new agreement on the deadlines, prices, contract renegotiation and conflict resolution, which, despite few citations, had occurrences close to those found for the topics of the Internal control category. The need to adapt and negotiate during the phase in which the administrative contracts are executed is often determined by the conditions of rendering services that had not been foreseen in the contract, be it because of the limited rationality of the managers, or due to failures in specifications.

As to the topics related to renegotiating prices and delivery dates, most of what was said by the interviewees highlights that these are frequent, legitimate demands which have naturally been authorized when duly proven. Despite this, as presented by the interviewees, this process of making new agreements about deadlines and prices is still very laborious (I10 and I11) and "has led to many doubts for public managers", declares the legal representative of the CEF (I13) (Author et al., 2013, p. 57).

Regarding the contract renegotiations, the situation is more complex because of the legal restrictions. Among the main factors that give rise to renegotiations are: failures that occurred in the contracting process, such as predatory behavior by the companies that participated in the tender when presenting the prices (I8), changes of scenario (I16), changes in the reality (I18), lack of flexibility to change rules defined ex-ante (I11) and failures in detailing and specification, as well as the connivance of some public managers (I19). As to this last factor, it is appropriate to present the explanation given in one of the interviews made with a private manager (I19):

There is an economic interest in the tender, and the federal and state agencies are also not very favorable to this [impugning the tender] unless it is a very gross error; because, one might say, that they also have an interest in their works being built. So there are a few things about which at the time of the tender, we might say this off the record, the companies and agencies already know that some adjustments will have to be made (Author et al., 2013, p. 57).

As to alleging that there is connivance among the public managers with mistakes during the tendering stage, a statement made by the coordinator of tenders at CAIXA/RS (I7) must be emphasized. She mentions lack of planning as a possible cause of this problem. Because projects are not available and because of the possibility 
that funds may have to be returned, the public managers may be encouraged to allow even projects with mistakes to go through the tendering process.

Regarding the topic or resolution of conflicts, the interviewees initially pointed out the flaws in the specification of contracts (I5, I17 and I19) and then the deviations in the services contracted for and in the demands presented during the execution phase as the main factors that lead to the use of conflict resolution mechanisms. Among the mechanisms commonly used to resolve these conflicts, the interviewees emphasize the use of informal meetings and then frequent follow-up of the contract execution. Although these meetings are informal mechanisms to resolve the conflicts, they are feasible and sometimes the most adequate mechanism to solve performance problems before taking stricter formal actions or actions with higher costs for the parties involved, such as a case in which the contract has to berescinded.

Finally, the terms of analysis of the subcategory Adaptation that occurred less in the utterances of the interviewees were the modifications in the objects contracted and the concession of amendments. The former, according to two interviewees, is rare and occurs only in very specific situations, because of legal limitations. The latter, in turn, is considered natural in contracts, although not very common, except for contracts on engineering works.

In the second subcategory, Deviations and penalties, an attempt was made to identify the perception of the players interviewed about possible opportunistic conducts of the suppliers, the occurrence of frauds and collusions and applying penalties and impugnation. In the case of tenders, the participants may act opportunistically when the state agencies do not specify the product tendered completely and especially when the participants to not trust the capacity and quality of the inspection and monitoring of the performance by the government. Thus, suppliers can use this contractual incompleteness to quote worse quality products, or products that do not correspond to the purchaser's needs (I15 and I16); or, in the cases of skepticism regarding the monitoring capacity, they may reduce the prices below the market prices during the contracting process, expecting to win the tender and to get adjustments and amendments during contract execution (I4, I5, I6, I8 and I19). Further, in more serious cases, they may not supply all the items contracted for or do not act in accordance with labor and social security laws (I5 and I10).

The scenario described before - possibility of opportunistic behavior - demonstrate the important role played by penalties and sanctions provided for in legislation and established in the contracts. However, recent studies such as that performed in Italy by Spagnolo (2012) show that the penalties in general are not applied correctly, since in that country it was found that over $30 \%$ of the public contracts analyzed were not fulfilled according to what was contracted for. 
Although there is no access to data about the number of penalties and sanctions applied in the public organizations surveyed in this study, an argument that could be used to explain the assumption that there is a low level of penalties for the irregularities committed in the Brazilian governmental procurement processes is the fact that the bureaucratic processes needed to implement these sanctions and penalties in general are slow and their costs are sometimes greater than the amounts associated with the losses incurred by the suppliers, as can be seen in the utterances of interviewees I2, I4, I5, I8, I19 and others. It should be highlighted that the only utterance that did not question the efficacy of the penalties was by a representative of the legal department (I13), which shows a mismatch between those responsible for managing the execution of contracts and those responsible for applying penalties.

The last topic for analysis in the subcategory Deviations and penalties refers to frauds and collusions and no such case was presented in the interviews analyzed. However, it should be pointed out that because of the low capacity to monitor and inspect contracts identified previously problems of fraud are potentiated, since the contractors may undertake activities designed to reduce the costs of the contract, for instance by altering the quality standards.

As to the dimension of Quality, the interviewees reported the mismatch between what was intended and what was in fact delivered, especially in the service contracts. This condition may be the result of two failures in management that were found in the other subcategories, namely: the low capacity to follow up the contract execution and the problems in contract specification (I19). The same observation was made by the coordinator of tenders at CAIXA/RS (I7), as can be seen in the following passage: "There are lots of mistakes in projects, because the CAIXA works with outsourced projects, with engineering offices that are outsourced and also outsourced inspection, so it is the offices under contract that make the projects to be tendered. There are many mistakes in the projects" (Author et al., 2013, p. 60).

Given the information presented throughout this section, a summary table was prepared containing the main perceptions of the managers and private players interviewed about the execution of administrative contracts in the public sector for the categories that presented occurrences of observations that were: High $(>50 \%)$ and Moderate (30\% to 50\%). Summary Table III below summarizes the main points found in the analysis of interview content.

Table III - Summary of the findings made in the analysis of the category Execution

\begin{tabular}{|c|c|c|c|c|}
\hline & Subcategory & Topic analyzed & $\begin{array}{c}\text { Occurrence } \\
\text { during } \\
\text { interviews }\end{array}$ & Main observations \\
\hline EXexecC & $\begin{array}{c}\text { Internal } \\
\text { Control }\end{array}$ & $\begin{array}{c}\text { Specification of the } \\
\text { object }\end{array}$ & High & $\begin{array}{c}\text { Management failures that affect project } \\
\text { performance }\end{array}$ \\
\hline
\end{tabular}




\begin{tabular}{|c|c|c|c|}
\hline & $\begin{array}{l}\text { Follow-up of } \\
\text { execution and } \\
\text { inspection }\end{array}$ & & \\
\hline \multirow{6}{*}{ Adaptation } & $\begin{array}{l}\text { Renegotiation of } \\
\text { deadlines }\end{array}$ & \multirow{2}{*}{ Moderate } & \multirow{2}{*}{$\begin{array}{c}\text { Something natural in the reality of } \\
\text { administrative contracts, but very } \\
\text { onerous in terms of time and resources } \\
\text { needed for analysis }\end{array}$} \\
\hline & $\begin{array}{l}\text { Renegotiation of } \\
\text { prices }\end{array}$ & & \\
\hline & $\begin{array}{l}\text { Renegotiation of } \\
\text { contracts }\end{array}$ & Moderate & \multirow{2}{*}{$\begin{array}{l}\text { Generated by uncertainties and by } \\
\text { opportunistic conducts. Management } \\
\text { performed with the support of informa } \\
\text { mechanisms and frequent follow-up }\end{array}$} \\
\hline & Conflict Resolution & Moderate & \\
\hline & $\begin{array}{l}\text { Change of contracted } \\
\text { object }\end{array}$ & Low & 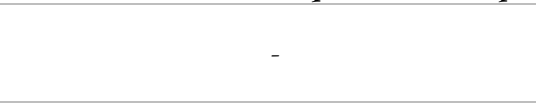 \\
\hline & $\begin{array}{l}\text { Concession of } \\
\text { amendments }\end{array}$ & Low & - \\
\hline \multirow{3}{*}{$\begin{array}{l}\text { Deviations } \\
\text { and Penalties }\end{array}$} & $\begin{array}{c}\text { Opportunistic } \\
\text { conducts of suppliers }\end{array}$ & Moderate & $\begin{array}{c}\text { Associated with failures in management } \\
\text { pointed out in the Internal Control } \\
\text { category }\end{array}$ \\
\hline & $\begin{array}{l}\text { Penalties and } \\
\text { impugnation }\end{array}$ & High & $\begin{array}{c}\text { High cost of implementation and low } \\
\text { effectiveness }\end{array}$ \\
\hline & Frauds/collusions & Low & - \\
\hline \multirow{2}{*}{$\begin{array}{l}\text { Quality of } \\
\text { contracting }\end{array}$} & $\begin{array}{l}\text { Satisfaction with the } \\
\text { contracted items }\end{array}$ & High & $\begin{array}{l}\text { Strong association with the iems of the } \\
\text { Internal control category }\end{array}$ \\
\hline & $\begin{array}{l}\text { Satisfaction with } \\
\text { deadlines }\end{array}$ & Moderate & $\begin{array}{l}\text { Control measures easy to apply in the } \\
\text { cases with the greatest frequency of } \\
\text { problems }\end{array}$ \\
\hline
\end{tabular}

Source: Author et. al. (2013, p.60)

\section{ON THE PURSUIT OF REALIZATION OF THE CONSTITUTIONAL PRINCIPLE OF EFFICIENCY}

On the basis of the results collected in the survey, it becomes clear that there is a great clash between flexibilization and control in the management of administrative contracts by state agencies. However, a few warnings are necessary.

First of all one should distinguish between direct administration and indirect administration. As regards the structure of public administration on the federal level, the direct administration comprises the services included in the administrative structures of the Presidency of the Republic and States, of the Federal District and Municipalities; it must comply with the principles of legality, impersonality, morality, publicity and efficiency. In its turn the indirect administration comprises categories of entities that are corporate entities by themselves: a) autarchies, b) public companies; c) private-public companies; and d) publicfoundations. 
As to the action of the public authority, there are bodies whose mission is to provide public services to society and, on the other hand, bodies that work as "economic agencies of the State" because they act directly in the economic domain. The latter include the public companies and private-public companies. It is clear that on a private level the main objective of companies is to make a profit. The same rule goes for public companies and private-public companies. In a highly competitive market, an excessively bureaucratic management model means a stiffening of the State business, especially when private companies are taken as a paradigm. This was reported on several occasions in the interviews performed, particularly those of theCAIXA/RS.

Since they are active in the market, these public entities (or predominantly public ones, in the case of private-public companies) have very different objectives from the public entities whose attribution is to provide public services. Accordingly, it is important to highlight the characteristics of a bureaucratic public administration, so as to distinguish it from managerial publicadministration.

In this sense, Christine Oliveira Peter da Silva teaches (1999, p.9):

Bureaucratic public administration thus emerged from the need to develop a type of administration that would be based not only on the clear distinction between public and private, but also on the separation between the political being and the public administrator. Thus, it developed from the concept of a capitalist bureaucratic organization based on centralizing decisions, on hierarchy and on the principle of the unity of command, on the pyramidal structure of power, on step by step control of administrative procedures. It actually consisted of a state bureaucracy of administrators who were specially trained to be suspicious of all and everyone, considering that the tradition informed that if it were not so, the "phantoms" of patriarchy and nepotism might resuscitate.

Managerial public administration has the basic foundation a state and a democratic and pluralistic society. In this society, citizens positioning themselves in order to safeguard their interests and ideologies. In managerial public administration, therefore, the state must take into account and respect the views of its citizens (Silva, 1999: 9)

In the current legislative system, the management of execution of administrative contracts by state agencies is eminently repressive. Besides, a great amount of time is expended by public employees during the period in which the administrative cases are processed to apply penalties, to mention only a few serious consequences of the bureaucratic public administration system. These impacts are felt even harder in the public entities that act in the economic sector. It should be mentioned that there is already a provision which authorizes such innovations as regards public companies and private-public companies, according to art. 173, $\$ 1$, III of the Federal Constitution (instituted by the Constitutional Amendment 19/1998, which established the principle of efficiency in Public Administration), thus only needing to be regulatedinfra-constitutionally.

That said, it is proposed to draft a regulatory document that institutes a simplified system of tenders and management of administrative contracts for the public companies and private-public companies. It embodies an appropriate model to the specificities of the activities carried out by such bodies, viz. the model of managerial 
public administration, having "trust" and freedom in managing the execution of administrative contracts as a rule and not as an exception - just as occurs today -,enabling greater speed to follow the evolution of the market and aiming at broadening business through a control done essentially by results, based on what is established by the contractual instruments. In this sense, the Differential Contracts Law (no 12462/2011) instituted the criterion to judge a proposal based on the greatest economic return (arts. 18, V and 23) and the contracts in which the variable remuneration is connected to the performance of the contractor (art. 10) based on the efficiency of contracts made in search of results.

\section{ON THE NEED TO CREATE A SINGLE COMPUTERIZED SYSTEM FOR CONTRACT EXECUTION MANAGEMENT}

As highlighted, a large part of the difficulty of gaining access to information about the management of administrative contracts lies in the absence or insufficiency of a database which has technological resources sufficiently apt to systematize and control the execution stages. Often, the absence of transparency in administrative contract management makes it impossible for social players such as the Prosecutors' Office, the Federal Audit Court, the General Comptrollership of the Federal Government and others to act plurally and at multiple levels. Sometimes the inspection is made only after the contracts have ended.

Thus, if there is a federal single system that covers updated information on the management of administrative contracts, through real time inspection it is possible to anticipate various irregularities in contracts and/or in the execution of contracts. And also, if this database were centralized, it would make public access easier - and be in perfect harmony with the law oftransparency.

Furthermore, the evaluation of previous contract performance by the participants in the tender could be used, based on the institution of a system of objective evaluation, besides utilizing a register of bad suppliers. This would ensure that the Administration will not make a contract with persons or companies forbidden to participate in tenders or to sign contracts because a sanction has been applied to them. Consequently, relevant aspects to be considered include seeking results as a way of making contracting more efficient, based on the criterion of judgment of a proposal with the highest economic return, as well as on contracts where the variable remuneration is linked to the contractor's performance.

In this sense, access could be made available in three user modalities: general, responsible for imputation and fiscal, respectively representing civil society, agents of the public organizations responsible for managing the execution of administrative contracts and entities with the power-duty of inspection established by law, thus creating different levels of access to the information from the database. 
Thus, it is proposed that, by means of legislation, the Single Computerized System for Contract Execution Management be implemented, creating a specific department to manage this database and establishing a deadline for the entities of Public Administration to adapt to the new guidelines.

\section{ON THE PROPOSITION OF A REGISTER OF GOOD SUPPLIERS}

Aiming to discipline consumer protection, Law 12527, of 2011, was introduced into the Brazilian legal system in order to regulate access to information, contained in subsection XXXIII of art. 5 , in subsection II of $₫ 3$ of art. 37, and in $₫ 2$ of the Federal Constitution, with the purpose of implementing a policy of public transparency in order to restore the credibility of state agencies in the eyes of society, above all after a succession of political scandals. This enables a pluridimensional control of the public budget since, once this information is available above all on the internet -, it gives a greater amplitude to participation in the management of the public patrimony by very different sectors of society, such as non-governmental organizations, the Prosecutor's Office, Public Defenders, trade unions and trade associations, amongothers.

According to art. 7, VI of Law 12527/2011, access to information presented by this regulatory document includes, among others, the information pertaining to the administration of public patrimony, use of public resources, tenders and administrative contracts. In the transparency portal, among other information, it is possible to consult the National Register of Ineligible and Suspended Companies, created for the purpose of publicly listing businesses and persons who were sanctioned by the agencies and entities of the Public Administration. However, in a completely opposite direction, there is no register of good suppliers and service providers.

In the sphere of consumption, for instance, the usefulness of the safety of contracting with good payers, i.e. to have a positive register of consumers, has already been realized. In this sense Law 12414/2011 was enacted, which rules on the establishment and consultation of databases with information on discharge of payments by persons or businesses to create a credit history. Some of those classified as good payers, in the terms of the regulatory document abovementioned, received some benefits such as easier credit from financial institutions.

Despite not having been raised a possible solution in the speech of respondents, the research group through the study proposes the development of a regulatory text to institute positive list of good suppliers and service providers in order to stimulate the competitiveness of companies that contract with the government in a healthy way. Thus, those framed in such registration profile should be evaluated within objective criteria, considering the absence of administrative penalties, meeting regularly retained deadlines in contract, sustainability policy, and certifications, among others, being published annual ranking of providers, correspondent the previous year. 
The implementation of this register would bring advantages for both sides: on the one hand, the State would stimulate excellent services, leading to greater competition among the contractors; on the other, the service providers would use this ranking as material proof of the quality of their services, which would possibly lead to an expansion of business and increased profitability. ${ }^{10}$ As a criterion to break the tie between two or more proposals, the evaluation of previous contract performance of the tenderers ca be used, as long as this objective evaluation system has already been instituted (art. 25, II, of Law no 12462/2011). Currently there are registers of bad suppliers (for example, the List of Ineligible Businesses of the Federal Audit Court), since this makes the Administration secure against contracting with anyone forbidden to participate in tenders or to make contracts due to a sanction applied.

Thus, it is proposed to enact laws that can institute the establishment and consultation of databases with information about good and bad suppliers and service providers in the federal sphere, covering persons and businesses, to create a database with all of the pertinent history along the lines of the provisions contained in Law $12414 / 2011$

\section{CONCLUSIONS}

The scope of the research project presented to the Department of Legislative Affairs of the Brazilian Ministry of Justice was to perform a survey on the management of the execution of administrative contracts by the Federal Public Administration, so that, based on the present situation detected, it would be possible to help solve the deficiencies and render public management more efficient. Various contracts of CAIXA/RS, INFRAERO/RS and FIOCRUZ/BA were looked at and used as investigative instruments.

After a qualitative and quantitative survey, the main flaws detected were: lack of flexibility in the contracting process; low capacity for monitoring and inspection; absence of adequate computerized systems to follow up the contracts; high costs involved in applying administrative sanctions; and low level of incentives for innovation. Thus, four central axes are extracted for theoretical discussion, with the main flaws found, in order to propose operational improvements to the current management model for the execution of administrative contracts:

1. Non-systematic interpretation of the current law by the public administrators, ignoring the constitutional principles that rule PublicAdministration;

\footnotetext{
${ }^{10}$ In this sense, and only to illustrate the point, Petrobras already has awarded the best suppliers of goods and services, ranking them according to the category of services and goods supplied. Retrieved from http://fatosedados.blogspetrobras.com.br/2012/11/28/petrobras-premia-os-melhores-fornecedores-de-bens-e-servicos-dabacia-de-campos
} 
2. Deficiencies in the inspection of the execution of administrative contracts both because of lack of staff and because of the lack of infrastructure for adequate management, going against already existing legal provisions;

3. Little flexibility in contracting and in the management of the execution of administrative contracts when related to the level of control adopted;

4. Lack of efficientist models in Public Administration.

Thus, a few proposals were presented aiming at improving the management of the execution of administrative contracts. As regards Axis I, it is proposed to build awareness among public agents about the modern view of the fundamental right to good administration ${ }^{11}$, since they are also the guardians of the constitutional principles.

As regards Axis II, it is suggested that periodical training of the inspectors of the execution of administrative contracts be performed in order to meticulously detail the legal provisions that are applicable and to renew their knowledge.

As to Axis III, it is proposed that public employees periodically attend training and refresher courses, aiming at: a) esteem for dialogue with the contractor, ensuring them of the possibility of an adversarial response and a broad defense in case of an alleged irregularity; b) incorporation of the notion of tempered legality, i.e. without the thoughtless absolutization of the rules and taking care that the constitutional principles are fulfilled; and c) building awareness of the need to act efficiently and efficaciously, as well as in an economically and teleologically responsible manner, besides reducing intertemporal conflicts that only raise transactional costs either because they use up the time of public employees or simply because they use up funds.

As regards Axis IV, the following propositions are made: (1) maintenance of the same percentages of profitability defined in the contract, in order to prevent the contractor from having losses or gains that were not foreseen at the time the contract was made; (2) a constant follow-up of the main indicators that show the efficiency or not of given practices adopted by the contractors and by the Administration itself, thus enabling the avoidance of deviations and irregularities, and also that good practices be optimized or extended to other sectors of the Administration or even of the contractor; and (3) creating more effective repressive measures since, as we saw in several situations, the amount of the fines and their slow application ultimately make the concessionaire believe that it is more profitable to pay the fine and continue to commit the same irregularities, instead of adopting practices that are adequate for the good and faithful fulfillment of the contract.

\footnotetext{
${ }^{11}$ In this view, the fundamental right to good administration proves to be a new profile of citizenship: "the citizen (not a simple 'administrated person') tends to be proactive and protagonistic, less passive and subject, in the administrative relations that are now proceduralized, and to demand technical and reasonable solutions" (Freitas, 2009, pp. 45-46).
} 
As regards the legislative proposals to improve the current management model for the execution of administrative contracts by state agencies, in brief the following suggestions aremade:

1. Creation of a register of good and bad suppliers (positive/negative register);

2. Implementation of a differential system of tenders for public companies and private-public companies, including the creation of an electronic catalogue for standardization;

3. Institution of a criterion to judge proposals based on the greatest economic return, with contracts in which the variable remuneration is connected to the contractor'sperformance;

4. Creation of a Computerized Single System for the Management of Contract Execution.

It is also proposed that there be greater control of execution, including applying an administrative penalty substantiated by law if public employees do not fulfill itcompletely.

Finally, the present work sought to outline possible routes to solutions of the main problems encountered in the research project involving management of the execution of administrative contracts by the government, without claiming to have covered all aspects of such a broad and controversial topic.

\section{MECANISMOS DE TRANSPARENCIA E GESTÃO DE CONTRATOS PÚBLICOS NO BRASIL: TRÊS ESTUDOS DE CASO NA ADMINISTRAÇÃO PÚBLICA FEDERAL}

\section{Resumo}

O objetivo geral do trabalho foi analisar mecanismos de gestão da execução de contratos administrativos pelos órgãos da Administração Pública Federal, como fiscalização, controle de qualidade e prazos, aplicação das sanções jurídico-administrativas e promoção da transparência, de modo a proteger o interesse público envolvido, bem como produzir diagnósticos capazes de gerar alternativas para superar os principais problemas e indefinições presentes no processo de gestão, tendo em vista o caráter interdisciplinar da pesquisa com base no aporte de distintas regiões do Brasil. A metodologia da pesquisa empírica baseou-se no aspecto quantitativo, a partir de tabelas variáveis, e no aspecto qualitativo, a partir da riqueza das informações colhidas. Os resultados apresentados demonstraram que o pregão eletrônico preponderou como modalidade licitatória dos contratos pesquisados. Isso colaborou para estabelecer as conclusões acerca das propostas de aprimoramento legislativo apresentadas, inclusive com a possibilidade de implementação de controle da execução dos contratos administrativos por resultados.

Palavras-chave: Gestão Administrativa de Contratação Pública Federal; Eficientismo; Modelos de gestão privada. 


\section{REFERENCES}

BRASIL MINISTÉRIO DO PLANEJAMENTO, ORÇAMENTO E GESTÃO. País apresenta sistema de compras governamentais em feira de tecnologia na Alemanha. Retrieved from http://rfbrasil.jusbrasil.com.br/politica/8458121/pais-apresenta-sistema-de-compras-governamentais-em-feira-detecnologia-na-alemanha

CABRAL, S., LAZZARINI, S. G. \& AZEVEDO, P. F. 2010. "Private Operation with Public Supervision: Evidence of Hybrid Modes of Governance in Prisons." Public Choice, Vol. 145, n. 1, p.281-193.

CARVALHO FILHO, J. dos S. 2008. Manual de Direito Administrativo (19 ed.). Rio de Janeiro: Lumen Juris.

CRESWELL, J. W. 1998. Qualitative inquiry and research design: choosing among five traditions. Thousand Oaks: Sage Publications.

DALEN, D. M., MOEN, E. R. \& RIIS, C. 2006. "Contract renewal and incentives in public procurement." International Journal of Industrial Organization, Vol. 24, n. 2, p. 269-285.

$\begin{array}{lllll}\text { PETROBRAS. Fatos } & \text { e } & \text { dados, } & \text { Retrieved }\end{array}$ http://fatosedados.blogspetrobras.com.br/2012/11/28/petrobras-premia-os-melhores- fornecedores-de-bense-servicos-da-bacia-de-campos

FERNANDES JÚNIOR, O. \& FURTADO, C. 2005. "Políticas Públicas: o poder de compra do Governo."

Desafios do Desenvolvimento, Vol. 2, n. 10. Retrieved from http://desafios.ipea.gov.br/index.php?option=com_content\&view=article\&id=885:reportagens-

materias\&Itemid $=39$

FIUZA, E. P. S. 2012. "O Regime Diferenciado de Contratações Públicas e a agenda perdida das compras públicas." Radar: tecnologia, produção e comércio exterior, Vol. 19, p. 7-20. Retrieved from http://www.defesanet.com.br/docs1/ipea_radar19.pdf

FREITAS, J. 2009. O controle dos atos administrativos e os princípios fundamentais (4 ed.). São Paulo: Malheiros.

HART, O., SHLEIFER, A. \& VISHNY, R. W. 1997. "The Proper Scope of Government: Theory and an Application to Prisons." Quarterly Journal of Economics, Vol. 112, n. 4, p.1127-1161.

LYOTARD, J.-F. 1979. La condition postmodern. Paris: Les Éditions deMinuit.

SILVA, C. O. da. 1999. “A reforma administrativa e a Emenda no 19/98: uma análise panorâmica." Revista Jurídica

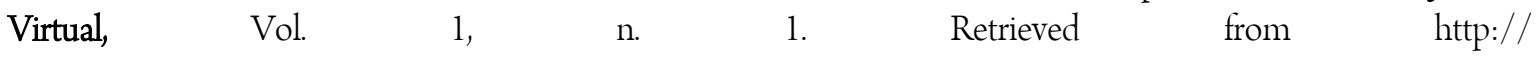
www.planalto.gov.br/ccivil_03/revista/Rev_01/Reforma\%20Administrativa.htm

SIMON, H. A. 1951. "A Formal Theory of the Employment Relationship." Econometrica (Amsterdam), Vol. 19, n. 3, p. 293-305.

SPAGNOLO, G. 2012. "Reputation, Competition, and Entry in Procurement." International Journal of Industrial Organization, Vol. 30, n. 3, p.291-296. 
TADELIS, S. 2012. "Public procurement design: Lessons from the private sector." International Journal of Industrial Organization, Vol. 30, n. 3, p. 297-302.

TORRES, R. C. L. de. 2008. Leis de licitações públicas comentadas. Salvador: Juspodivm.

WILLIAMSON, O. E. 1985. The economics institutions of capitalism. London: FreePress.

Trabalhoenviadoem21 dedezembrode2015.

Aceitoem28demarçode2016. 